\title{
The Development of Realistic Mathematics Education Based Learning Tools to Improve Mathematical Problem Solving Ability and Self-Efficacy on Students in Junior High School 1 Lubuk Pakam
}

\author{
Delima Manurung ${ }^{1}$, P. Siagian ${ }^{2}$, Ani Minarni ${ }^{2}$ \\ ${ }^{1}$ Master Student in Universitas Negeri Medan, Medan, Indonesia \\ ${ }^{2}$ Lecturer in Universitas Negeri Medan, Medan, Indonesia \\ Manurung_delima@ymail.com
}

\begin{abstract}
This study aims to 1) Produce the valid, practical, and effective of Realistic Mathematics Education based learning tools; 2) Analyzing the improvement of students' mathematical problem solving ability that are learned using Realistic Mathematics Education-based learning tools; and 3) Analyzing the achievement of students' self-efficacy who are taught using Realistic Mathematics Education-based learning tools. The subjects in this study were seventh grade students of Junior High School 1 Lubuk Pakam. Data collection instruments in this development are assessment instruments to assess the products that have been developed. In addition, students were given questionnaires to get data about students' Self-Efficacy. This research is Research and Development with the design of learning development models by Dick and Carey. The steps include: 1) Conducting preliminary research; 2) Making software design; 3) Collecting the materials; 4) Developing the contextual based interactive multimedia; 5) Product reviews and trials; and 6) the effectiveness of product test. The results showed Realistic Mathematics Education-based learning tools on students' mathematical problem solving ability increased from trial I to trial II with an average increase per indicator of $0.35 \%$; $3.99 \%$; $16.22 \%$ and $8.32 \%$. The developed learning tool has fulfilled the effective criteria, namely the mastery learning of students classically in the first trial has reached a good category and in the second trial has reached a very good category; the achievement of student learning goals during learning activities meet the ideal criteria specified; student responses is positive to the components of learning tools and learning activities developed; and the allocation of ideal time usage.
\end{abstract}

Keywords

learning tods, realistic

mathematics education;

mathematical problemsolving

ability, self-efficacy

\section{Introduction}

Thinking ability to solve problems and have confidence in self ability to solve mathematical problems is a very basic and very important part. Although problem solving is an integral part of mathematical problems, many students struggle with problem solving. Burns (in Culaste, 2011), "Ability to solve word problems falls far below their ability to compute because children do not know how to choose the correct operation to apply to the problem". The research shows that students' ability to solve problems is far from their ability to count because students do not know how to choose the correct operation to apply to the mathematical problem.

Based on the TIMSS survey (Trends in International Mathematics and Science Study) conducted by IAE (The International Association for the Evaluation and Educational 
Achievement), in 1999, Indonesia obtained an average rating of 403 and occupies $34^{\text {th }}$ position out of 38 countries, in 2003 obtained an average rating of 411 and occupies $35^{\text {th }}$ position out of 46 countries, in 2007 obtained an average rating of 397 occupies 36th position out of 49 countries, in 2011 obtained an average rating of 386 occupies $38^{\text {th }}$ position out of 42 countries, and most recently in 2015 at position 45 out of 50 countries in mathematics. The average standard score set by TIMSS is 500, which means that Indonesia's position in each of its participation always gets a score below the average set (Arsaythamby Veloo, et al. 2015).

The low TIMSS results can be caused by several factors. One of them is the lack of skills in problem solving. Mathematics learning is not only directed at increasing students 'ability to count, but also directed at improving students' abilities in problem solving. Therefore, learning and questions that require the ability to solve problems must be used early. As said by Napitupulu, Suryadi \& Kusumah (2016: 118) that children who are involved in problem solving activities automatically build their reasoning abilities.

In addition to the general facts of the TIMSS results, the facts in the field are based on observations made by the authors at Junior High School 1 Lubuk Pakam and interviews with several mathematics teachers at the school, that mathematics is still a difficult and confusing subject for most students. For example in social arithmetic material, students find it difficult to determine the selling price, the purchase price, the percentage of profit, and the percentage of loss of an item even though these things are often faced by students in daily life.

The ability of students in learning mathematics, especially problem solving is still relatively low. This is obtained when the researcher makes preliminary observations by giving test questions about mathematical problem solving abilities on social arithmetic material whose analysis is based on indicators of problem solving ability.

To support learning in addition to textbooks, worksheets are also a learning support component. According to Trianto (2011: 222) Student Activity Sheet (Worksheet) is a student guide that is used to carry out investigation or problem solving activities. The worksheet in the form of a guide to exercise the development of cognitive aspects as well as a guide to the development of all aspects of learning. The worksheet contains a set of basic activities that must be carried out by students to maximize understanding in the effort to form basic abilities according to indicators of achievement of learning outcomes that must be taken.

To see the achievement of learning outcomes test results are needed. According to Trianto (2011: 235) the learning achievement test is a test item used to determine student learning outcomes after participating in teaching and learning activities. The learning achievement test is made in reference to the basic competencies to be achieved. The learning achievement test developed is adjusted to the level of cognitive ability. Learning Outcomes Test, Student Activity Sheet (worksheet), textbooks and Learning Implementation Plan are learning tools that must be possessed by teachers to be implemented in daily learning practices in education units.

Based on the author's observation, the reality and condition of teachers in Junior High School 1 Lubuk Pakam apparently most of the teachers have not been able to compile learning devices properly, the equipment set by the teachers is not good, among others, caused by the teacher's understanding of the way of preparing learning tools that are still very less. In the learning process, the teachers only use makeshift books, that is, use books provided by the school. Next is the lesson plan, teacher and student books on social arithmetic materials used in Junior High School 1 Lubuk Pakam.

Addressing the problems that occur in the field so far that is in the process of learning mathematics in schools, especially those relating to the importance of mathematical problem 
solving ability and self-efficacy of students that have an impact on the low learning outcomes of mathematics. The Government of Indonesia in this case the Ministry of Education and Culture has actually anticipated it by making some curriculum changes. In the period of 2000 until now there have been three types of curriculums applied, namely the 2004 curriculum, the 2006 curriculum, and the 2013 curriculum. Although the curriculum was changed, preliminary observations showed that the function and role of the teacher in learning mathematics specifically related to how to deliver subject matter remained unchanged. Yusrizal, I. Hajar and S. Tanjung (2019) said the teacher was responsible for improving student learning outcomes, one of the ways that could be taken was to create active teaching and learning activities.

\section{Review of Literature}

\subsection{Mathematical Problem Solving Ability}

One ability that is expected to be mastered by students in mathematics is problem solving. To be able to solve problems, one can use mathematical knowledge previously obtained as provisions to solve new problems. Problem solving learning is basically learning to use scientific methods or think systematically, logically, orderly, and thoroughly. The goal is to gain cognitive abilities and abilities to solve problems rationally, straightforwardly, and completely. Problem solving is the process of students discovering mathematics, and is the purpose of mathematics. Through problem solving also students can learn the contents and processes of mathematics. Problem solving is a means for students to develop their mathematical ideas. This is consistent with the statement issued by NCTM that "all students should build new mathematical knowledge through problem solving".

Problem solving is a combination of process and skill. Problem solving is a process because students learn about mathematical ideas. Through exploring problems, students develop their understanding of mathematical concepts and develop their mathematical skills (Susan O'Connell, 2007: 21). The various definitions of problem solving outlined above indicate that a new problem is truly said to have been resolved if the student understood what he was doing, namely understanding the problem solving process and knowing why the solution obtained was appropriate.

Some ways to help students overcome difficulties solving problems include: a) asking questions to direct students to work; b) present a signal (clue or hint) to resolve the problem and not provide a resolution procedure; c) help students explore their knowledge and arrange their own questions according to the needs of the problem; d) help students overcome their own difficulties. In this study, students' mathematical problem solving ability is the ability of students to solve mathematical problems that are not routinely reviewed in terms of (a) understanding the problem; (b) making a problem-solving plan; (c) carry out the plan; and (d) recheck answers.

\subsection{Self-Efficacy Dimension}

According to Bandura (Setiadi, 2010) the measurement of self-efficacy of a student refers to three dimensions, namely:

a. Level (difficulty level of the problem). Indicators relating to the level of difficulty of the problem are given. The ability of students to solve problems with different levels of difficulty. Students with high self-efficacy will have high confidence about the ability to solve difficult mathematical problems, conversely students who have low self-efficacy will also have low beliefs about the ability to solve mathematical problems which they consider 
difficult. Students will try to solve the problems that they perceive can be resolved, and he will avoid problems that he perceives outside his ability.

b. Strength (resilience), this indicator is related to the strength of confidence in his ability, or a confidence that exists in someone who can be realized in achieving a particular performance. Students have a strong belief in solving the mathematical problems they face, even though these problems are difficult. The stronger self-efficacy, the greater the perseverance, so the higher the likelihood of the problem chosen to be solved.

c. Generality, an indicator of self-efficacy related to the broad scope of the field of behavior in which students feel confident about their abilities. Students are able to assess their confidence in solving mathematical problems given in various materials or in certain materials only. Whether or not someone is able to solve mathematical problems in a particular material or a variety of materials reveals a general picture of the student's selfefficacy.

To improve students' self-efficacy, there are several strategies that can be carried out, namely:

a. Teach students with a special approach so that they can improve their ability to focus on their assignments.

b. Guide students in setting goals, especially in making short-term goals after they make longterm goals.

c. Give rewards for student performance.

d. Combine training strategies with an emphasis on objectives and provide feedback to students about learning outcomes.

e. Provide support or support to students. Positive support can come from the teacher such as the statement "you can do this", and others.

f. Convince that students are not too worried because it will actually reduce student selfefficacy.

g. Provide students with positive models such as peers and adults. Certain characteristics of the model can increase students' self-efficacy. Modeling is effective for increasing self-efficacy especially when students observe the success of their peers who actually have the same abilities as them.

\subsection{Realistic Mathematics Education Approach}

The learning approach can be interpreted as a starting point or point of view of the teacher towards the learning process, or the way taken by the teacher and students in achieving the learning objectives seen how the material is presented. There are two types of approaches, namely: teacher-centered approaches and student-centered approaches.

The Realistic Mathematics Education Approach is one of the student-centered approaches. Learning mathematics through Realistic Mathematics Education which is then abbreviated as PMR is an approach to learning mathematics that expresses experiences and events that are close to students as a means to understand mathematical problems. This approach to learning mathematics was developed since 1971 by a group of mathematicians from the Freudenthal Institute, Utrecht University in the Netherlands, they called it Realistic Mathematics Education. This approach is based on the assumption of Hans Freudenthal (1905 1990), an educator and mathematician, who thinks that mathematics is a human activity. $\mathrm{He}$ stated that students could not be considered as passive recipients of mathematics learning, but mathematics learning should provide opportunities for students to rediscover mathematical knowledge by utilizing various opportunities and real situations experienced by students. 
The principle of rediscovery can be inspired by informal solving procedures, while the process of reinvention uses the concept of mathematization. There are two types of mathematization formulated by Treffers (Van Den Heuvel: 1995), namely horizontal mathematization (model-of) and vertical (model-for) mathematics. The examples of horizontal mathematization are the identification, formulation and visualization of problems in different ways, and the transformation of real world problems into mathematical problems. The examples of vertical mathematization are representation of relationships in formulas, improvement and adjustment of mathematical models, the use of different models, and generalization. Both types of mathematicization need to get balanced attention, because both of these mathematics have the same score.

\section{Research Method}

This type of research is Research and Development with the design of learning development models by Dick and Carey. The steps include: 1) Conducting preliminary research; 2) Making software design; 3) Collecting the materials; 4) Developing the contextual based interactive multimedia; 5) Product reviews and trials; and 6) Product effectiveness test. This research was conducted at Junior High School 1 Lubuk Pakam. The subjects in this study were seventh grade students of Junior High School 1 Lubuk Pakam. Data collection instruments in this development are assessment instruments to assess the products that have been developed. In addition, students were given questionnaires to get data about students' selfefficacy. In addition, data collection in this study is a test of students' mathematical problem solving ability, tests are used to assess students' ability after being taught with learning devices that have been developed. Before the test is used, first the test is tested for validity, reliability, difficulty level, and different power of the questions.

\section{Discussion}

\subsection{Results}

\section{Practicality Analysis of Realistic Mathematics Education Based Learning Tools in Trial I}

Realistic Mathematics Education -based learning tools are said to be practical in terms of (1) expert / practitioner assessment of the learning tools developed that are stated to be used with little or no revision; (2) the observation results of the learning tools feasibility in classrooms are included in the minimum high category $\left(3 \leq \mathrm{P}^{-}<4\right)$. The following will be presented a discussion for each indicator in measuring the practicality of Realistic Mathematics Education -based learning tools in trial I.

a. The Expert / Practitioner's Assessment of Learning Tools

Based on the mastery of the theory and experience of experts and practitioners states that the learning tools with the Realistic Mathematics Education approach can be used with a little revision. To prove that statement, the learning tools and instruments that are already valid are tested in the field (in the implementation of learning in class). The results will be explained in the next point, namely the implementation of learning tools.

b. The Implementation of Trial Learning Tools I

The implementation of the learning tools through the Realistic Mathematics Education approach was measured using an observation sheet of the implementation of Realistic Mathematics Education based learning tools. The results of observational data analysis of 
the implementation of Realistic Mathematics Education-based learning tools concluded that the achievement of the level of implementation of learning devices in the first trial was included in the high category which means that Realistic Mathematics Education-based learning devices were said to be practical or applicable. The average observational score of the learning kit for each meeting in trial I is shown in the following table.

Table 1. The Average Observation Score of the Implementation of Trial Learning Tools I

\begin{tabular}{|c|c|c|c|c|c|c|}
\hline $\begin{array}{c}\text { Overall Average of 2 } \\
\text { Observers }\end{array}$ & \multicolumn{4}{|c|}{ Meetings } & \multirow{2}{*}{ Total Average } & \multirow{2}{*}{ Information } \\
\cline { 2 - 5 } & $\mathbf{1}$ & $\mathbf{2}$ & $\mathbf{3}$ & $\mathbf{4}$ & \\
\hline Trial Test I & 3,75 & 3,88 & 3,63 & 3,81 & 3,77 & High \\
\hline
\end{tabular}

Based on the table above, it is found that, on average, 2 (two) observers for the first trial, the first meeting was 3.75 , for the second meeting was 3.88, for the third meeting was 3.63 , and for the fourth meeting was 3.81. Furthermore, for the average total score of the four meetings was 3.77 which is in the high category $(3 \leq \bar{P}<4)$. Thus it can be concluded that the Realistic Mathematics Education-based learning tools developed are practical in terms of the implementation of the learning tools.

\section{The Analysis of Draft II Effectiveness Results on the Field Trial I}

The learning tools based on the Realistic Mathematics Education approach are said to be effective in terms of classical student mastery learning, that is, at least $85 \%$ of students who participate in learning are able to achieve a score of $\geq 75$, the achievement of learning objectives, and student responses. The results of the effectiveness of the draft-2 for each indicator are described as follows.

a. Classical Learning Completeness of Students

To see the effectiveness of a learning device one of them is to see the level of mastery after being given or using a learning device that was developed. In research the level of student mastery in terms of the ability to solve mathematical problems using the test of mathematical problem solving abilities that were developed get an average score of 76.4. Based on the level of mastery of students' mathematical problem solving abilities from the results of the first test posttest can be seen in the following table.

Table 2. Mathematical Problem Solving Ability of Posttest Results in Trial I

\begin{tabular}{|c|cc|c|c|c|}
\hline No. & \multicolumn{2}{|c|}{ Interval Score } & Students Number & Percentage & Score Category \\
\hline 1. & $0 \leq$ Total Score TKPM & $<45$ & 0 & $0 \%$ & Unsatisfied \\
\hline 2. & $45 \leq$ Total Score TKPM & $<65$ & 5 & $16,67 \%$ & Poor \\
\hline 3. & $65 \leq$ Total Score TKPM & $<75$ & 2 & $6,67 \%$ & Moderate \\
\hline 4. & $75 \leq$ Total Score TKPM & $<90$ & 22 & $73,33 \%$ & Good \\
\hline 5. & $90 \leq$ Total Score TKPM & $\leq 100$ & 1 & $3,33 \%$ & Very Good \\
\cline { 3 - 6 } & & & & $<100$ &
\end{tabular}

TKPM Information $=$ Problem Solving Ability Test

Furthermore, the results of classical completeness of students' mathematical problem solving ability in field trials I can be seen in the following table.

Table 3. Classical Completeness of Mathematical Problem Solving Ability in Trial I

$$
\text { Category }
$$$$
\text { Mathematical Problem Solving Ability }
$$ 


\begin{tabular}{|l|c|c|}
\hline & Students Number & Percentage \\
\hline Complete & 23 & $76,67 \%$ \\
\hline Not complete & 7 & $23,33 \%$ \\
\hline amount & 30 & $100 \%$ \\
\hline
\end{tabular}

Based on the data in the table, it can be seen that the mastery of student learning classically from the results of the mathematical problem solving ability of 30 students is the number of students who are complete is 23 students (76.67\%) and the number of students who are not complete is 7 students $(23.33 \%)$. In accordance with the criteria of completeness of student learning classically, that is at least $85 \%$ of students who take learning are able to achieve a score of $\geq 75$. Thus the results of the posttest mathematical problem-solving ability in field trials I have not met the criteria for achievement of classical completeness. So, it can be concluded that in the first field trial the application of the PMR-based learning tools that were developed did not meet the classical achievement criteria for completeness.

\section{Student Questionnaire Results}

The student response questionnaire was conducted to see the extent of student interest, feelings of pleasure and recency and ease in understanding components such as material / content of teaching materials, formats, pictures, activities in Student Book, Student Activity Sheets, and learning atmosphere. This response questionnaire was given after all teaching and learning activities were completed.

Student responses to learning and the tools used in learning include positive responses and negative responses. Positive responses are characterized by positive statements such as happy, new, and interested in the components of learning tools developed based on Realistic Mathematics Education. While negative statements are marked with statements such as displeased, not new and not interested in using the components of learning tools developed based on Realistic Mathematics Education.

Based on the analysis of student questionnaire responses, it can be seen that the percentage of results from the first aspect, the percentage of students who stated they were happy with the subject matter reached 90\%, students who liked the student book $93.33 \%$, then students who were happy about the worksheet component was $90 \%$, while students who are happy with the atmosphere of learning in the classroom are $90 \%$ and the percentage of students who are happy with the way teachers manage learning is $90 \%$. In the aspect of student responses to the components of the learning device also looks very good, this can be seen from the percentage of students who state that the learning device components are new for each category reaching $83.33 \%, 90 \%, 90 \%, 86.67 \%$, and $83,33 \%$.

In the third aspect of student interest, namely whether students are interested or not interested in participating in learning activities. Out of 30 students, 27 students (90\%) expressed interest while 3 students (10\%) expressed no interest in reasoning that learning always discussed worksheets, and students were not ready or not brave when asked to advance to class representing their groups to present their work. While students who expressed interest in giving comments or reasons that students when actively involved in learning, students conducted activities to find mathematical concepts and were given the opportunity to ask questions and give opinions in learning.

In the fourth aspect, the percentage obtained for each category was $83.33 \%$ and $86.67 \%$. So from the results of student responses to this fourth aspect, it can be seen that students can already understand the language used in the components of the developed learning device. The 
fifth aspect is obtained $90 \%$ and $90 \%$ respectively for each category. From the results of this aspect it can be understood that students are interested in the writing and pictures contained in the student book and Student Activity Sheet.

\section{Practicality Analysis of Realistic Mathematics Education Based Learning Tools in Trial II}

Realistic Mathematics Education-based learning tools are said to be practical in terms of (1) expert / practitioner assessment of the learning tools developed that are stated to be used with little or no revision; (2) the results of observations of the feasibility of learning tools in classrooms are included in the minimum high category $(3 \leq \bar{P}<4)$. The following will be presented a discussion for each indicator in measuring the practicality of Realistic Mathematics Education-based learning tools in trial II.

a. The Expert / Practitioner's Assessment of Learning Tools

Based on the mastery of the theory and experience of experts and practitioners states that the learning tools with the Realistic Mathematics Education approach can be used with a little revision. To prove that statement, the learning tools and instruments that are already valid are tested in the field (in the implementation of learning in class). The results will be explained in the next point, namely the implementation of learning tools.

b. The Implementation Analysis of the Trial Learning Tools II

The effectiveness of the learning tools through the Realistic Mathematics Education approach was measured using an observation sheet of the implementation of Realistic Mathematics Education-based learning tools. The results of observational data analysis of the implementation of Realistic Mathematics Education-based learning tools concluded that the achievement of the level of implementation of learning tools in Trial II was included in the high category, which means that Realistic Mathematics Education-based learning tools were said to be practical or applicable. The average score of observing the use of learning tools for each meeting in trial II is shown in the following table.

Table 4. The Average Observation Score of the Implementation of Trial Learning Tools II

\begin{tabular}{|c|c|c|c|c|c|c|}
\hline \multirow{2}{*}{$\begin{array}{c}\text { Overall Average of } 2 \\
\text { Observers }\end{array}$} & \multicolumn{4}{|c|}{ Meetings } & \multirow{2}{*}{ Total Average } & \multirow{2}{*}{ Information } \\
\cline { 2 - 6 } & $\mathbf{1}$ & $\mathbf{2}$ & $\mathbf{3}$ & $\mathbf{4}$ & \\
\hline Trial Test II & 3,94 & 4,00 & 3,88 & 3,94 & 3,94 & High \\
\hline
\end{tabular}

Based on the table above, it is found that, on average, 2 (two) observers for the first trial, the first meeting was 3.94, for the second meeting was 4.00 , for the third meeting was 3.88 , and for the fourth meeting was 3.94. Furthermore, for the average total score of the five meetings was 3.94 which is in the high category $(3 \leq \bar{P}<4)$. Thus it can be concluded that the Realistic Mathematics Education-based learning tools developed are practical in terms of the implementation of the learning tools.

\section{The Analysis of Draft III Effectiveness Results in Field Trials II}

Previously it has been explained that a product that is developed has good quality if it fulfills three things, namely validity, practicality and effectiveness. Then the learning tools based on the Realistic Mathematics Education approach are said to be effective in terms of classical student mastery learning, at least $85 \%$ of students who take learning are able to achieve a score of $\geq 75$, the achievement of learning objectives, and the results of student 
questionnaire responses. The results of the draft 3 effectiveness for each indicator are described as follows.

a. Classical Learning Completeness of Students

To see the effectiveness of a learning device one of them is to see the level of mastery after being given or using a learning device that was developed. In research the level of student mastery in terms of mathematical problem solving abilities by using tests of mathematical problem solving abilities and self-efficacy by using a self-efficacy questionnaire that was developed. Tests and questionnaires are given after four learning meetings, the aim is to find out how the level of mastery and completeness of students to the subject matter they have learned. Criteria that state students are said to have mastered learning (individual completeness) mathematical problem solving ability and mathematical self-efficacy if the correct proportion of students is $\geq 75 \%$ and a class is said to have completed learning (classical completeness) if in the class there are $\geq 85 \%$ of students who have finished learning. A description of the results of students' mathematical problem solving abilities in trial II is shown in the following table.

Table 5. The Description Results of Mathematical Problem Solving Ability in Trial II

\begin{tabular}{|c|c|}
\hline Information & Score \\
\hline High Score & 94 \\
\hline Low Score & 70 \\
\hline Average & 84,19 \\
\hline
\end{tabular}

Based on the level of mastery of students' mathematical problem solving abilities on the results of the posttest II field trials can be seen in the following table.

Table 6. Mastery Ability Level of Mathematical Problem Solving Posttest Results in Field Trials II

\begin{tabular}{|c|c|c|c|c|c|}
\hline No. & \multicolumn{2}{|l|}{ Interval Score } & Students Number & Percentage & Score Category \\
\hline 1. & $0 \leq$.Total Score TKPM & $<45$ & 0 & $0 \%$ & Unsatisfied \\
\hline 2. & $45 \leq$ Total Score TKPM & $<65$ & 0 & $0 \%$ & Poor \\
\hline 3. & $65 \leq$ Total Score TKPM & $<75$ & 3 & $9,68 \%$ & Moderate \\
\hline 4. & $75 \leq$ Total Score TKPM & $<<90$ & 21 & $67,74 \%$ & Good \\
\hline 5. & $90 \leq$ Total Score TKPM & $\leq 100$ & 7 & $22,58 \%$ & Very Good \\
\hline
\end{tabular}

TKPM Information $=$ Problem Solving Ability Test

Furthermore, the results of classical completeness of students' mathematical problem solving abilities in field trials II can be seen in the following table.

Table 7. Classical Mastery Level of Mathematical Problem Solving Ability in Field Trials II

\begin{tabular}{|l|c|c|}
\hline \multirow{2}{*}{ Category } & \multicolumn{2}{c|}{ Mathematical Problem Solving Ability } \\
\cline { 2 - 3 } \multicolumn{1}{|c|}{ Students Number } & Percentage \\
\hline Complete & 28 & $90,32 \%$ \\
\hline Not complete & 3 & $9,68 \%$ \\
\hline amount & 31 & $100 \%$ \\
\hline
\end{tabular}




\section{Student Questionnaire Results}

Based on the results of the analysis of student questionnaire responses, it can be seen that the percentage of results from the first aspect, the percentage of students who expressed satisfaction with the subject matter reached $96.77 \%$, students who liked the student book $93.55 \%$, then students who liked the Woorksheet component were $96,77 \%$, while students who were happy with the learning atmosphere in the classroom were $96.77 \%$ and the percentage of students who were happy with the way the teacher managed learning was $100 \%$.

In the second aspect, the students' responses to the learning device components also look very good, this can be seen from the percentage of students who state that the learning device components are new for each category reaching 90.32\%, 93.55\%,93.55\%, $9032 \%$ and $96.77 \%$. In the third aspect of student interest, namely whether students are interested or not interested in participating in further learning activities. Of the 31 students, all expressed interest in participating in the learning. In the fourth aspect, out of 31 students 29 (93.55\%) students can clearly understand the language used in the Student Book and Student Activity Sheet. The fifth aspect is obtained $94 \%$ and $100 \%$ for each category. From the results of this aspect it can be understood that students are interested in the writing and pictures contained in student books and student worksheets.

From the results of student responses, the average percentage obtained for the first aspect is $96.77 \%$, the second aspect is $92.90 \%$, the third aspect is $100 \%$, the fourth aspect is $93.55 \%$, and the fifth aspect is $95.16 \%$. If referred to the student response categories, then overall student responses are in the very positive category. Thus, based on the results of student questionnaire responses to the components of Realistic Mathematics Education-based learning it can be said that all aspects of getting a positive response so that the components of this learning device are effective for use.

\subsection{Discussion}

\section{The Improvement of Students' Mathematical Problem Solving Ability by Using Realistic Mathematics Education-Based Learning}

Data obtained from the results of the posttest mathematical problem-solving abilities of students in the first and second trials were analyzed to determine the improvement in students' mathematical problem solving abilities by comparing the average student scores obtained from the results of the first and second trials. The improvement of students 'mathematical problem solving abilities is seen from the average posttest results of students' mathematical problem solving abilities. Improved students' mathematical problem solving abilities are also seen in each indicator of mathematical problem solving. This shows that the use of Realistic Mathematics Education-based learning developed has an impact on improving students' mathematical problem solving abilities.

There is an increase in students' mathematical problem solving abilities is a natural thing, because with the Realistic Mathematics Education approach students themselves find their knowledge and master the findings correctly, while the teacher's role is to guide students by giving direction and students are encouraged to think for themselves so they can find general principles based on directives / questions the questions given by the teacher and how far the students are guided depend on their abilities and the material being studied. Piaget's Theory (Dahar, 2006) also revealed that students should be encouraged to have their own opinions, express them, defend them, and feel responsibility for them. 


\section{The Achievement of Student Self-Efficacy by Using Realistic Mathematics Education- Based Learning}

Based on the results of the analysis of student self-efficacy questionnaire data in the first try and the second trial showed the achievement of good student self-efficacy. This is because mathematics learning with Realistic Mathematics Education-based learning tools presents meaningful learning with contextual problems that are closer to the student environment so as to make students actively interact both students and students with the teacher using previous experiences and knowledge students have had. This characteristic is relevant to Vygotsky's theory (in Ansari, 2012) because this theory states that children's intellectual development is influenced by social factors. The social and learning environment naturally influences children's development in increasing cognitive complexity and systematicism.

According to Bandura (Setiadi, 2010) the measurement of self-efficacy owned by a student refers to three dimensions, namely: (1) level (level of difficulty of the problem); (2) strength (resistance); and (3) generality. Level dimension, students with high self-efficacy will have high beliefs about the ability to solve difficult mathematical problems, conversely students who have low self-efficacy will also have low beliefs about the ability to solve mathematical problems that are considered difficult. Students will try to solve the problems that they perceive can be resolved, and they will avoid problems that they perceives outside their ability.

Strength dimensions, this indicator is related to the strength of confidence in his ability, or a confidence that exists in someone who can be realized in achieving a particular performance. Students have a strong belief in solving the mathematical problems they face, even though these problems are difficult. The stronger self-efficacy, the greater the perseverance, so the higher the likelihood of the problem chosen to be solved.

On generality dimension, the indicator of self-efficacy is related to the broad scope of behavior where students feel confident about their abilities. Students are able to assess their confidence in solving mathematical problems given in various materials or in certain materials only. Whether or not someone is able to solve mathematical problems in a particular material or a variety of materials reveals a general picture of the student's self-efficacy.

Based on the above it shows that the Realistic Mathematics Education-based learning approach is significantly better in achieving students' self-efficacy. So it can be concluded that the use of Realistic Mathematics Education-based learning can be used in achieving good student self-efficacy.

\section{Conclusion}

From the results of the research that has been done, the conclusions can be described were: Realistic Mathematics Education-based learning tools on students' mathematical problem solving ability increased from trial I to trial II with an average increase per indicator of $0.35 \%$; $3.99 \% ; 16.22 \%$ and $8.32 \%$. The developed learning tool has fulfilled the effective criteria, namely the mastery learning of students classically in the first trial has reached a good category and in the second trial has reached a very good category; the achievement of student learning goals during learning activities meet the ideal criteria specified; student responses is positive to the components of learning tools and learning activities developed; and the allocation of ideal time usage. 


\section{References}

Culaste, I. C. 2011. Ognitive Skill of Mathematical Problem Solving of Grade 6 Children. International Journal of Innovative Interdisciplinary Research, 1, 120-125.

Setiadi, Riswanda. 2010. Self-Efficacy. Bandung: Rizky Press.

Sugiman dan Kusumah. 2010. Dampak Pendidikan Matematika Realistik Terhadap Peningkatan Kemampuan Pemecahan Masalah Siswa SMP. Jurnal Pendidikan Volume 1 Nomor 1.

Van Den Heuvel, Panhuize. (1995). Mathematics Education In Netherlands: A Guide Tour ${ }^{\text {. }}$ Standards For Mathematics Education. Utrecht, the Netherlands: Freudenthal Institute

Trianto, 2011. Mendesain Model Pembelajaran Inovatif-Progresif. Jakarta: Kencana.

Yusrizal, I. Hajar, S. Tanjung. 2019. Analysis of Elementary School Teachers' Ability in Using ICT Media and Its Impact on the Interest to Learn of Students in Banda Aceh. Budapest International Research and Critics in Linguistics and Education (BirLE) Journal. 2 (3): 37-49. 